\title{
MEASUREMENTS OF SERUM MÜLLERIAN INHIBITING SUBSTANCE IN THE EVALUATION OF CHILDREN WITH NONPALPABLE GONADS
}

\author{
Mary M. Lee, M.D., Patricia K. Donahoe, M.D., Bernard L. Silverman, M.D., Tomonobu Hasegawa, M.D., \\ Yukihiro Hasegawa, M.D., Michael L. Gustafson, M.D., YuChiao Chang, Ph.D., \\ AND David T. Maclaughlin, Ph.D.
}

\begin{abstract}
Background Müllerian inhibiting substance, produced constitutively by the prepubertal testes, promotes involution of the müllerian ducts during normal male sexual differentiation. In children with virilization and nonpalpable gonads, only those with testicular tissue should have detectable serum concentrations of müllerian inhibiting substance.

Methods We measured serum müllerian inhibiting substance in 65 children with virilization at birth and nonpalpable gonads (age at diagnosis, 2 days to 11 years) and serum testosterone in 54 of them either after the administration of human chorionic gonadotropin or during the physiologic rise in testosterone that occurs in normal infants.

Results The mean $( \pm \mathrm{SD})$ serum müllerian inhibiting substance concentration in the 17 children with no testicular tissue was $0.7 \pm 0.5 \mathrm{ng}$ per milliliter, as compared with $37.5 \pm 39.6 \mathrm{ng}$ per milliliter in the 48 children with testes $(P<0.001)$. In the latter group, the mean values in the 14 children with abnormal testes and the 34 with normal testes were 11.5 \pm 11.8 and $48.2 \pm 42.1 \mathrm{ng}$ per milliliter, respectively $(\mathrm{P}<$ $0.001)$. The sensitivity and specificity of the serum müllerian inhibiting substance assay for detecting the absence of testicular tissue were 92 percent and 98 percent, respectively, as compared with 69 percent and 83 percent for the measurement of serum testosterone. Furthermore, measurement of serum müllerian inhibiting substance was more sensitive than serum testosterone measurement for the identification of children with abnormal testes (67 percent vs. 25 percent), whereas the specificity of the two tests was similar.
\end{abstract}

Conclusions Measurements of serum müllerian inhibiting substance can be used to determine testicular status in prepubertal children with nonpalpable gonads, thus differentiating anorchia from undescended testes in boys with bilateral cryptorchidism and serving as a measure of testicular integrity in children with intersexual anomalies. (N Engl J Med 1997;336:1480-6.)

(C)1997, Massachusetts Medical Society.

$\mathrm{T}$ HE accurate identification of abdominal gonads is essential for evaluating children with virilization and nonpalpable gonads. Gonadal biopsies provide definitive diagnoses, but the gonads may be difficult to find, and operative exploration is invasive and may compromise the gonadal tissue. Radiologic imaging, though noninvasive, may miss abdominal gonads. ${ }^{1,2}$ Measurement of serum gonadotropins is helpful in agonadal infants and peripubertal children but is often nondiagnostic in midchildhood. ${ }^{3,4}$ Therefore, the primary method of gonadal evaluation in prepubertal children has been to determine the response of serum testosterone to the administration of human chorionic gonadotropin..$^{5-10}$ The ability to detect a circulating hormone produced constitutively by prepubertal testes, but not ovaries, would obviate the need for provocative testing.

Müllerian inhibiting substance, ${ }^{11}$ or anti-müllerian hormone, ${ }^{12}$ a gonadal hormone that promotes the involution of the müllerian ducts during normal male sexual differentiation, is secreted in such a sexually dimorphic pattern..$^{13}$ The absence of müllerian inhibiting substance in female embryos is necessary for the müllerian ducts to differentiate into the uterus, oviducts, and upper vagina. ${ }^{14}$ Testicular secretion of müllerian inhibiting substance commences by the eighth week of gestation and persists postnatally, whereas ovarian production starts after birth. ${ }^{15}$ Serum concentrations of müllerian inhibiting substance are readily detectable in boys from birth to puberty, when the concentrations decline, but are negligible in girls until puberty. ${ }^{13,16-18}$ We undertook this study to determine whether measurements of serum müllerian inhibiting substance would help identify abdominal testes in boys with bilateral cryptorchidism and facilitate gonadal evaluation in children with intersexual disorders.

\section{METHODS}

\section{Study Subjects}

We studied 65 children ranging in age from 2 days to 11 years who were referred to Massachusetts General Hospital (Boston), Children's Memorial Hospital (Chicago), or Kiyose Children's Hospital (Tokyo, Japan) for the evaluation of cryptorchidism or ambiguous genitalia. Blood samples for the measurement of serum müllerian inhibiting substance were obtained in conjunction

From the Pediatric Surgical Research Laboratory (M.M.L., P.K.D., M.L.G., D.T.M.), Pediatric Endocrine Unit (M.M.L.), and Medical Practices Evaluation Center (Y.C.), Massachusetts General Hospital and Harvard Medical School, Boston; the Department of Pediatric Endocrinology and Diabetes, Children's Memorial Hospital and Northwestern Medical School, Chicago (B.L.S.); and the Division of Endocrinology and Metabolism, Tokyo Metropolitan Kiyose Children's Hospital, Tokyo, Japan (T.H., Y.H.). Address reprint requests to Dr. Lee at the Pediatric Endocrine Unit, ACC 709, Massachusetts General Hospital, Boston, MA 02114. 
with the collection of samples for other laboratory studies, with oral parental consent, according to approved institutional guidelines. All the children studied had no palpable gonads and were virilized, with the phenotype ranging from clitoromegaly with otherwise normal appearing female genitalia to normally developed male genitalia. All subsequently either underwent surgical exploration or had spontaneous testicular descent. The assignment of sex was based on the diagnosis, the degree of virilization, the karyotype, and potential fertility and sexual function. The 65 children were ultimately grouped diagnostically as those with anorchia, abnormal testes, normal testes, or ovaries (Table 1).

\section{Serum Müllerian Inhibiting Substance Assay}

Serum müllerian inhibiting substance was measured by an enzyme-linked immunosorbent assay as described previously. ${ }^{13,17,19}$ The limit of sensitivity of the assay was $0.5 \mathrm{ng}$ per milliliter, and the intraassay and interassay coefficients of variation were 9 percent and 15 percent, respectively. Undetectable values were assigned a value of $0.5 \mathrm{ng}$ per milliliter. The results in the 65 study subjects were compared with those in 438 normal children of similar ages $(<1$ month, $\geqslant 1$ month to $<24$ months, $\geqslant 2$ years to $<6$ years, and $\geqslant 6$ years to $<12$ years). ${ }^{13}$ The respective mean (and lowest) values for boys in each of the successive age groups were 22.6 (3.2), 84.0 (6.4), 63.8 (7.0), and 43.0 (0.8) ng per milliliter, and the respective mean values for girls were $0.6,0.9,1.4$, and $2.7 \mathrm{ng}$ per milliliter, with the majority of values being undetectable in girls.

\section{Other Hormonal Assays}

Serum testosterone was measured before and after the administration of two to six injections of human chorionic gonadotropin at a dose of 1500 IU per square meter of body-surface area in 44 of the children. The results were compared with published data obtained with similar testing regimens. ${ }^{6-8,10}$ In 10 other children, serum testosterone was measured basally during early infan$c y$, a period when the values in normal children are elevated because the hypothalamic-pituitary-gonadal axis is transiently activated. ${ }^{20,21}$ In the remaining children, serum testosterone was measured basally at ages when the values are indistinguishable between boys and girls and therefore nondiagnostic. Serum testosterone was measured by radioimmunoassay in the clinical laboratories of the referring centers, as was serum follicle-stimulating hormone.

\section{Statistical Analysis}

We used Kolmogorov-Smirnov statistics to compare the distribution of serum müllerian inhibiting substance values among the four groups of children. The 95 percent confidence intervals of the test characteristics (sensitivity, specificity, and positive and negative predictive values) were obtained with exact interval estimation..$^{22,23}$

\section{RESULTS}

\section{Serum Müllerian Inhibiting Substance Concentrations}

Serum müllerian inhibiting substance concentrations in the children with anorchia, abnormal testes, normal testes, or ovaries are shown in Figure 1. The mean values differed significantly among the four groups $(\mathrm{P}<0.001)$, except between the children with anorchia and those with ovaries.

None of the 12 children with anorchia had identifiable gonadal tissue at surgery. Three had microphallus, but nine had normal phallic development. All had low or undetectable serum concentrations of müllerian inhibiting substance. Ten of these children received stimulation with human chorionic gonado-
Table 1. Final Diagnosis in 65 Children with Virilization and NonPalpable Gonads.

\begin{tabular}{|c|c|c|c|}
\hline Final Diagnosis & $\begin{array}{l}\text { No. of } \\
\text { ChILDREN }\end{array}$ & SeX & $\begin{array}{c}\text { Mean } \\
\text { Age (YR) }\end{array}$ \\
\hline Anorchia & 12 & & 4.1 \\
\hline Vanishing testes* & 12 & M & \\
\hline Abnormal testes & 14 & & 1.2 \\
\hline $\begin{array}{l}\text { Mixed gonadal dysgenesis } \\
\text { True hermaphroditism } \\
\text { Leydig-cell hypoplasia } \\
\text { Testicular regression* }\end{array}$ & $\begin{array}{l}7 \\
3 \\
1 \\
3\end{array}$ & $\begin{array}{c}6 \mathrm{~F} / \mathrm{l} \mathrm{M} \\
\mathrm{F} \\
\mathrm{M} \\
\mathrm{l} \mathrm{F} / 2 \mathrm{M}\end{array}$ & \\
\hline Normal testes & 34 & & 4.4 \\
\hline $\begin{array}{l}\text { Cryptorchidism } \\
\text { Bilateral cryptorchidism } \\
\text { Klinefelter's syndrome }\end{array}$ & $\begin{array}{r}23 \\
1\end{array}$ & $\begin{array}{l}\mathrm{M} \\
\mathrm{M}\end{array}$ & \\
\hline $\begin{array}{l}\text { Male pseudohermaphroditism } \\
\text { Idiopathic male pseudohermaphroditism } \\
\text { Androgen resistance } \\
\text { Disorder of testosterone synthesis } \\
\text { Secondary hypogonadism }\end{array}$ & $\begin{array}{l}4 \\
3 \\
2 \\
1\end{array}$ & $\begin{array}{c}1 \mathrm{~F} / 3 \mathrm{M} \\
\mathrm{F} \\
\mathrm{F} \\
\mathrm{M}\end{array}$ & \\
\hline Ovaries & 5 & & 0.2 \\
\hline $\begin{array}{l}46, \mathrm{XX} \text { congenital adrenal hyperplasia } \\
\text { Mild idiopathic clitoromegaly }(46, \mathrm{XX})\end{array}$ & $\begin{array}{l}4 \\
1\end{array}$ & $\begin{array}{l}\mathrm{F} \\
\mathrm{F}\end{array}$ & \\
\hline
\end{tabular}

*Vanishing testes and testicular regression refer to children with a 46,XY karyotype who have evidence of initial testicular formation with secondary regression of the testes. The degree of virilization and the extent of residual gonadal tissue vary and depend partly on the timing of the loss of testicular function.

†This boy with 46,XXY Klinefelter's syndrome was classified as having cryptorchidism because he had normal external male genitalia and normal immature testicular tissue on biopsy.

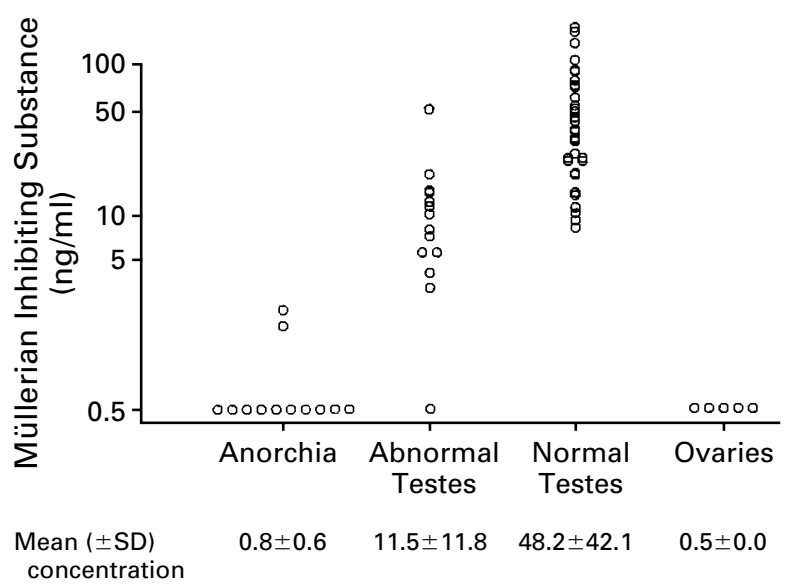

Figure 1. Serum Müllerian Inhibiting Substance Concentrations in Children with Anorchia, Abnormal Testes, Normal Testes, and Ovaries.

The mean $( \pm S D)$ serum müllerian inhibiting substance concentrations are listed below the graph for each group. 
tropin, which increased serum testosterone concentrations slightly to $40 \mathrm{ng}$ per deciliter $(1.39 \mathrm{nmol}$ per liter) in one but not in the other nine. Serum follicle-stimulating hormone concentrations were elevated (for age) in nine and normal in three, but the values did not correlate with those for either serum testosterone or müllerian inhibiting substance.

Fourteen children had histologically abnormal testes and various degrees of genital virilization: 11 had gonadal dysmorphogenesis including testicular dysgenesis, streak gonads, ovotestes, and Leydig-cell hypoplasia, and 3 had bilateral intrauterine torsion with gonadal atrophy. The mean $( \pm S D)$ müllerian inhibiting substance concentration was $11.5 \pm 11.8$ ng per milliliter in this group, and the values were at or below the fifth percentile of the values for normal children in 10 (71 percent) of these children (Fig. 2). In contrast, serum testosterone concentrations increased after the administration of human chorionic gonadotropin in all but one child. Eleven children in this group had elevated basal or stimulated serum testosterone concentrations of 59 to $405 \mathrm{ng}$ per deciliter (2.1 to $14.2 \mathrm{nmol}$ per liter).

Thirty-four children had normal testes verified by intraoperative examination, histologic assessment, or palpation after spontaneous descent; 24 of these children had bilateral cryptorchidism, and 10 had male pseudohermaphroditism. Four boys with bilateral cryptorchidism had hypospadias or microphallus, and 20 had normal external male genitalia. The extent of virilization of the children with male pseudohermaphroditism ranged from mild clitoromegaly to microphallus. The mean serum müllerian inhibit-

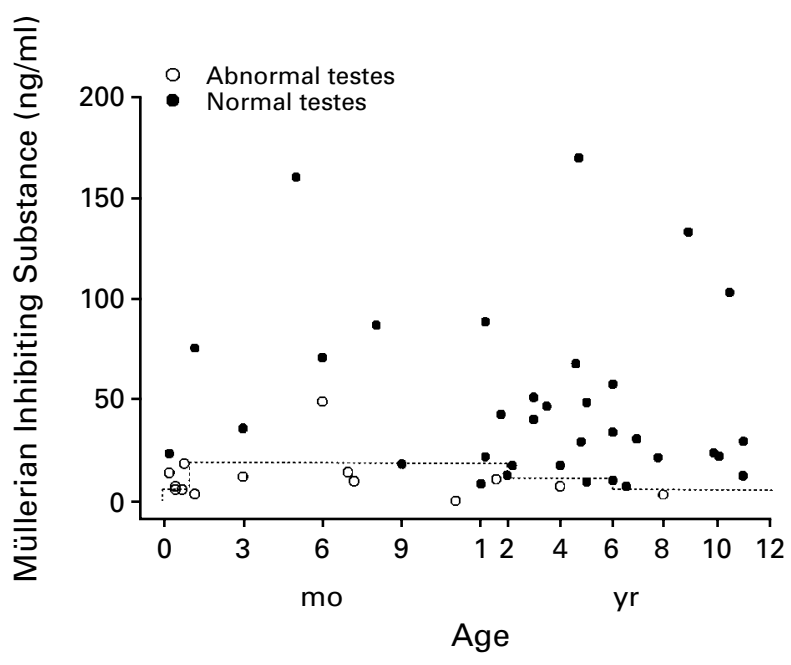

Figure 2. Serum Müllerian Inhibiting Substance Concentrations as a Function of Age in Children with Abnormal Testes and Those with Normal Testes.

The dotted line represents the fifth percentile of the values relative to age in normal boys. ing substance concentration in these children was $48.2 \pm 42.1 \mathrm{ng}$ per milliliter. The values were all within the normal range for boys, and only three were at or below the fifth percentile for age (Fig. 2). Of the 27 boys in whom serum testosterone values were measured after the administration of human chorionic gonadotropin, 19 (70 percent) had normal increases for age and 8 (30 percent) had subnormal increases. In two other boys with bilateral cryptorchidism, the basal serum testosterone values were elevated.

All five girls with female pseudohermaphroditism had undetectable serum müllerian inhibiting substance concentrations, whereas basal serum testosterone concentrations were elevated in three of the girls with a diagnosis of congenital adrenal hyperplasia.

Serum concentrations of müllerian inhibiting substance and testosterone were discordant in other children besides these girls. In four boys with bilateral cryptorchidism, serum müllerian inhibiting substance values were normal although serum testosterone values failed to increase with stimulation, whereas in four children with mixed gonadal dysgenesis and one with true hermaphroditism, serum müllerian inhibiting substance values were low but basal or stimulated serum testosterone concentrations were elevated.

\section{Determination of Testicular Status}

The mean serum müllerian inhibiting substance concentration in the 12 children with anorchia and the 5 children with ovaries was significantly lower than that in the 48 children with abnormal or normal testes $(0.7 \pm 0.5$ vs. $37.5 \pm 39.6$ ng per milliliter, $\mathrm{P}<0.001)$. The serum müllerian inhibiting substance concentration was both a sensitive and a specific indicator of the absence of testes (Table 2). The predictive value of a low concentration for the absence of testes was 89 percent, and that of a normal value for the presence of testes was 98 percent.

To compare the usefulness of serum müllerian inhibiting substance and testosterone determinations for identifying testicular tissue, a similar analysis was performed in 54 children in whom serum testosterone values were measured after stimulation with human chorionic gonadotropin in 44 and during the physiologic testosterone rise that occurs in normal infants in $10 .{ }^{20,21}$ Serum testosterone values were classified as normal if they were elevated above those present in females in the appropriate age group. The sensitivity and specificity of the müllerian inhibiting substance assay in this subgroup of children were similar to those in the entire group (Table 2). The sensitivity and specificity of the serum testosterone assay were 69 percent and 83 percent, respectively. Although the positive predictive value of a low serum testosterone value for the absence of testicular tissue was only 56 percent, normal serum müllerian 
Table 2. Value of Serum Müllerian Inhibiting Substance Assay FOR THE IDENTiFication Of Testicular Tissue. *

\begin{tabular}{|c|c|c|c|c|c|c|c|c|}
\hline \multirow[t]{3}{*}{ VARIABLE } & \multicolumn{2}{|c|}{ All Children } & \multicolumn{6}{|c|}{ Children in Whom Serum Testosterone Was Measured } \\
\hline & \multicolumn{2}{|c|}{ SERUM MIS } & \multicolumn{2}{|c|}{ SERUM MIS } & \multicolumn{2}{|c|}{$\begin{array}{c}\text { SERUM } \\
\text { TESTOSTERONE } \dagger\end{array}$} & \multicolumn{2}{|c|}{$\begin{array}{c}\text { MIS AND } \\
\text { TESTOSTERONE }\end{array}$} \\
\hline & Low & Normal & Low & Normal & Low & Normal & $\begin{array}{l}\text { Both } \\
\text { Low }\end{array}$ & $\begin{array}{l}\text { Either } \\
\text { Normal }\end{array}$ \\
\hline \multicolumn{9}{|l|}{ Testes } \\
\hline Absent & 16 & 1 & 12 & 1 & 9 & 4 & 8 & 5 \\
\hline \multirow[t]{3}{*}{ Present } & 2 & 46 & 1 & 40 & 7 & 34 & 0 & 41 \\
\hline & $\begin{array}{r}\text { Sens } \\
\text { TE } \\
\text { AbSEI }\end{array}$ & $\begin{array}{l}\text { TIVITY OF } \\
\text { it FOR } \\
\text { T TESTES }\end{array}$ & $\begin{aligned} & \text { SPECIFI } \\
& \text { FOF }\end{aligned}$ & $\begin{array}{l}\text { TY OF TEST } \\
\text { TESTES }\end{array}$ & PPV & OF TEST & NPV & OF TEST \\
\hline & \multicolumn{8}{|c|}{ percent (95 percent $\mathrm{Cl}$ ) } \\
\hline $\begin{array}{l}\text { All children } \\
\text { Serum MIS assay }\end{array}$ & \multirow{2}{*}{\multicolumn{2}{|c|}{$94(71-100)$}} & \multirow{2}{*}{\multicolumn{2}{|c|}{$96(86-100)$}} & \multirow{2}{*}{\multicolumn{2}{|c|}{$89(65-99)$}} & \multirow{2}{*}{\multicolumn{2}{|c|}{$98(89-100)$}} \\
\hline $\begin{array}{l}\text { Children in whom serum testos- } \\
\text { terone was measured }\end{array}$ & & & & & & & & \\
\hline Serum MIS assay & \multirow{3}{*}{\multicolumn{2}{|c|}{$\begin{array}{l}92(64-100) \\
69(39-91) \\
62(32-86)\end{array}$}} & \multirow{2}{*}{\multicolumn{2}{|c|}{$\begin{array}{l}98(87-100) \\
83(68-93)\end{array}$}} & \multirow{3}{*}{\multicolumn{2}{|c|}{$\begin{array}{c}92(64-100) \\
56(30-80) \\
100(63-100)\end{array}$}} & \multirow{3}{*}{\multicolumn{2}{|c|}{$\begin{array}{l}98(87-100) \\
90(75-97) \\
89(76-96)\end{array}$}} \\
\hline Serum testosterone test & & & & & & & & \\
\hline Both tests & & & 100( & $1-100)$ & & & & \\
\hline
\end{tabular}

${ }^{*}$ MIS denotes müllerian inhibiting substance, PPV positive predictive value, NPV negative predictive value, and CI confidence interval. Serum müllerian inhibiting substance values were considered normal if they were within the normal range for boys.

$\dagger$ Ten of the serum testosterone values were obtained basally during the physiologic peak that occurs in normal infants. All other values were obtained after the administration of human chorionic gonadotropin. Serum testosterone values were considered normal if they were above the normal range for girls.

inhibiting substance and testosterone values were both highly predictive of the presence of testicular tissue. The sensitivity and specificity of the combination of both tests for detecting the absence of testes were 62 percent and 100 percent, respectively.

\section{Discriminating between Abnormal and Normal Testes}

Among the 48 children with testicular tissue (14 with abnormal testes and 34 with normal testes), the sensitivity and specificity of the serum müllerian inhibiting substance assay for identifying abnormal testes were 71 percent and 91 percent, respectively (Table 3). For the presence of abnormal testes, the predictive value of a concentration below the fifth percentile for normal boys was 77 percent. For the presence of normal testes, the predictive value of a concentration at or above the fifth percentile was 89 percent.

Among the 41 children with testicular tissue in whom serum testosterone was measured, the sensitivity and specificity of the müllerian inhibiting substance assay were similar to those in the larger group of 48 children (Table 3 ). Serum testosterone values were classified as normal if basal values obtained during the physiologic peak that occurs in normal infants or values measured after stimulation with chorionic gonadotropin were in the normal range for boys. ${ }^{6-8,10}$ The serum testosterone assay was not sensitive (25 percent) in this group and was a poor predictor of abnormal testes (27 percent). Using both tests together decreased their sensitivity and increased their specificity. Therefore, the combination of low serum müllerian inhibiting substance and testosterone values was 100 percent predictive of abnormal testes, but there was only one child in this category.

\section{DISCUSSION}

These results demonstrate that measurement of serum müllerian inhibiting substance is a sensitive and specific test for the detection of testes in prepubertal children. A measurable value within the normal range for boys is predictive of testicular tissue, and an undetectable value is predictive of anorchia or ovaries. Serum concentrations of müllerian inhibiting substance differ quantitatively in children with abnormal and normal testes and, therefore, are also helpful for assessing the structural integrity of the testes. As compared with testing involving the administration of human chorionic gonadotropin, the measurement of serum müllerian inhibiting substance is more sensitive and equally specific, and its predictive value for the absence of testicular tissue is higher. Measurement of serum müllerian inhibiting substance is particularly useful in young children, because serum gonadotropin concentrations in those 


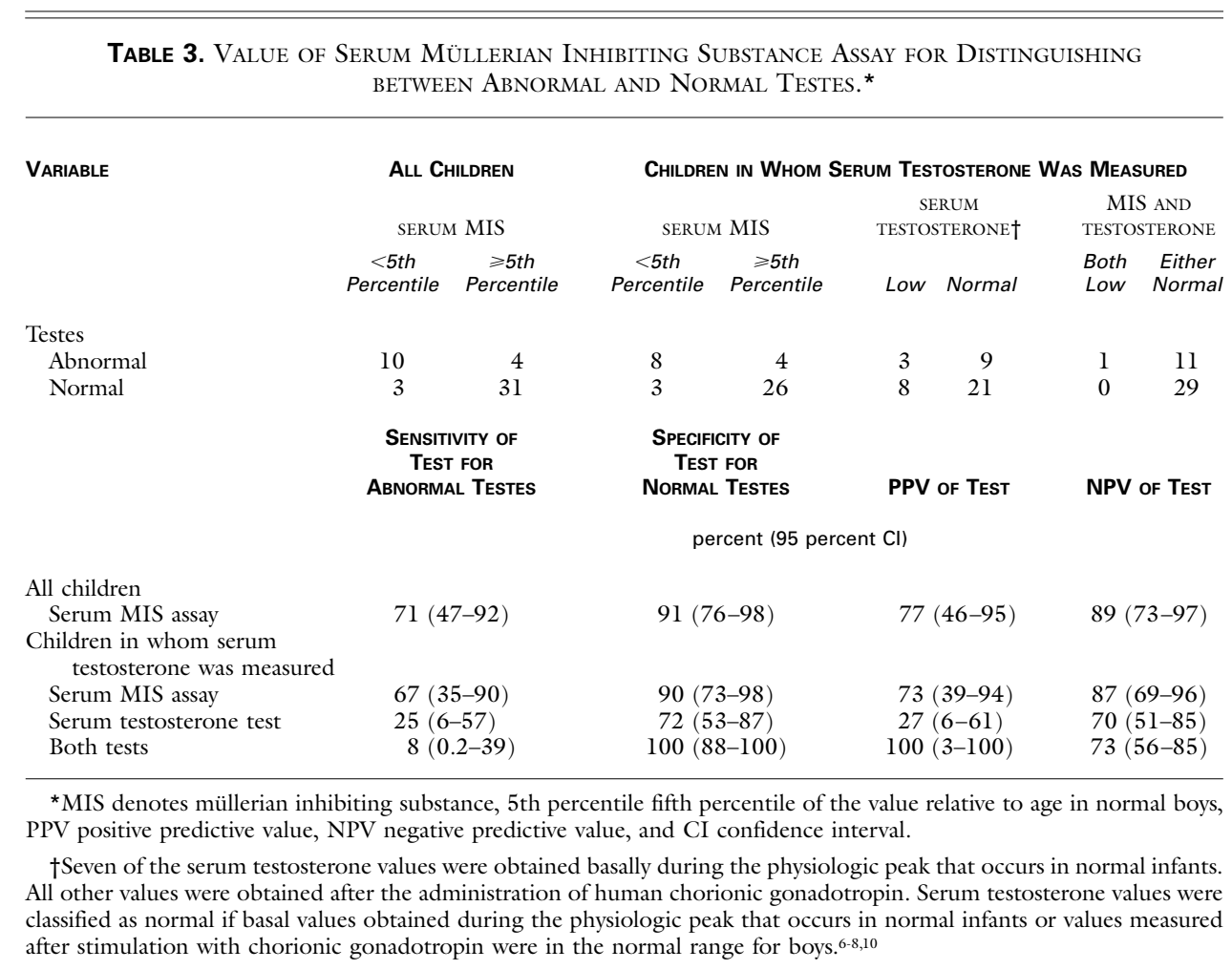

who are agonadal are nondiagnostic in midchildhood $^{4}$ and serum testosterone concentrations may fail to increase with provocative testing in children with abdominal testes, as found in this study. Measurement of serum müllerian inhibiting substance is also simpler, requiring only a single blood sample, than testing with human chorionic gonadotropin.

The presence of müllerian inhibiting substance in serum is a highly specific marker of testicular tissue in infants and prepubertal children. ${ }^{13,19,24,25}$ With pubertal maturation, testicular synthesis of this hormone declines, whereas ovarian synthesis increases, and serum concentrations overlap in men and women. ${ }^{13,26,27}$ Nevertheless, values above the normal range for women remain diagnostic of the presence of testicular tissue except in women with granulosa-cell tumors or sex-cord tumors that secrete müllerian inhibiting substance. ${ }^{28,29}$ Conversely, serum müllerian inhibiting substance concentrations may be low in a subgroup of children with the rare syndrome of persistent müllerian ducts despite the presence of structurally normal testes. ${ }^{30}$

Müllerian inhibiting substance is produced and secreted by Sertoli cells, and testosterone is produced and secreted by Leydig cells. Thus, the discordant serum müllerian inhibiting substance and testosterone values in some of the children in the study may reflect the disparate effects of abdominally positioned testes or gonadal dysgenesis on Sertoli and Leydig cells. Testicular function has traditionally been assessed by examining the steroidogenic capacity of Leydig cells and spermatogenesis. Assessment of the function of immature Sertoli cells may also be relevant, however, because Sertoli cells constitute the supporting cellular matrix for spermatogenesis and an adequate complement in the developing testes may be critical for the survival and maturation of germ cells. ${ }^{31}$ Long-term follow-up of the children with discordant results may resolve whether functional assessment of Sertoli cells or Leydig cells before puberty will be the better predictor of mature testicular function.

Several questions may arise during the evaluation of children with virilization and nonpalpable gonads. Are gonads present, and if so, are they normal? What is the potential for sexual and reproductive function? Is surgical exploration necessary? In this study, we found that measurement of serum müllerian inhibiting substance is a clinically useful and convenient test that can help answer these questions. We suggest that the test can best be used as outlined in Figure 3. In boys with bilateral cryptorchidism, determination of serum müllerian inhibiting substance should distinguish those with anorchia from those with abdominal testes; a value in the normal range for boys is sufficient to confirm that testicular tissue is present. Consequently, surgical exploration is necessary if the testes fail to descend spontaneous- 


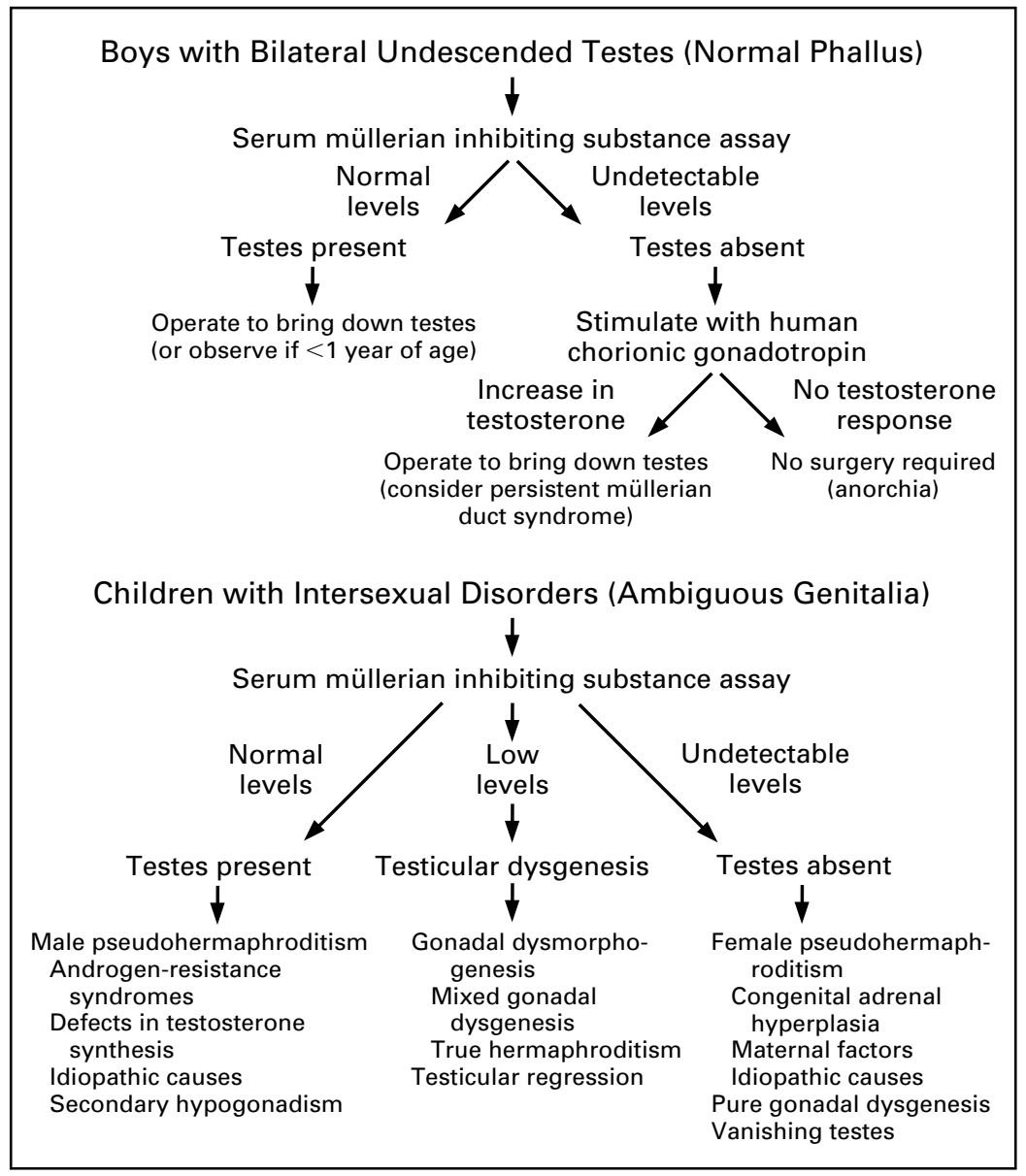

Figure 3. Interpretation of the Assay of Serum Müllerian Inhibiting Substance in the Evaluation of Boys with Bilateral Undescended Testes or Children with Intersexual Disorders.

ly during infancy. Conversely, if the serum müllerian inhibiting substance value is low, serum testosterone should be measured before and after the administration of human chorionic gonadotropin to verify the absence of testicular tissue or identify other cases of cryptorchidism. In children with intersexual disorders, the serum müllerian inhibiting substance value is a measure of the structural integrity of the gonads that helps delineate the cause of the disorder. A value in the normal range for boys indicates that morphologically normal testes are present and suggests that the child has a disorder of androgen action or biosynthesis. ${ }^{32}$ A low value suggests that the testes are dysgenetic, and an undetectable value suggests that the testes are absent, as would be the case in girls with female pseudohermaphroditism and pure gonadal dysgenesis. In children with intersexual disorders, measurement of serum müllerian inhibiting substance offers an additional index of testicular function but should not preclude testing involving stimulation with human chorionic gonadotropin, which is necessary for the definitive diagnosis of defects in the synthesis of testosterone. Moreover, as a highly specific test for the presence of testicular tissue, measurement of serum müllerian inhibiting substance will effectively identify unwanted residual testicular tissue in girls with true hermaphroditism who have undergone partial gonadectomies. ${ }^{19}$

Supported in part by grants from the Genentech Foundation for Growth and Development and the National Institute of Diabetes and Digestive and Kidney Diseases (DK-02129) (to Dr. Lee), a grant from the National Cancer Institute (CA 17393) (to Dr. Donahoe), a grant from the Food and Drug Administration's Orphan Drug Program (FD-R-000669) (to Dr. MacLaughlin), and a grant from the National Institute of Child Health and Human Development (2F32HD07435) (to Dr. Gustafson)

Presented at the 1996 Pediatric Academic Societies' Annual Meetings, Washington, D.C. (Pediatric Research 1996;39:92A).

We are indebted to Drs. Lynne L. Levitsky, Paul A. Boepple, Soja Park-Bennet, and John D. Crawford of the Pediatric Endocrine Unit and Drs. Daniel Ryan, Daniel Doody, and Samuel Kim of Pediatric Surgery at Massachusetts General Hospital for their clinical care and identification of study children; to the following physicians for contributing patients' data and serum for the determination of 
müllerian inhibiting substance: Samir Najjar and Alan Retik (Boston), Curtis Sheldon and Eric Smith (Cincinnati), Carolyn Becker (Danbury, Conn.), Gary Freidenberg (Indianapolis), Martin Goldsmith (Fresno, Calif.), Jerome Grunt (Kansas City, Mo.), Stuart Howards (Charlottesville, Va.), Robert McVie (Shreveport, La.), Sharon Oberfeld (New York), Harold Starkman (Morristown, N.J.), A. Winthrop (Hamilton, Ont., Canada), and Stephen Wolf (Des Moines, Iowa); and to Ms. Laura Asmundson and Ms. Gretchen B. Crist for technical assistance.

\section{REFERENCES}

1. Friedland GW, Chang P. The role of imaging in the management of the impalpable undescended testis. AJR Am J Roentgenol 1988;151:1107-11. 2. Hrebinko RL, Bellinger MF. The limited role of imaging techniques in managing children with undescended testes. J Urol 1993;150:458-60.

3. Jarow J, Berkovitz GD, Migeon CJ, Gearhart JP, Walsh PC. Elevation of serum gonadotropins establishes the diagnosis of anorchism in prepubertal boys with bilateral cryptorchidism. J Urol 1986;136:277-9.

4. Lustig RH, Conte FA, Kogan BA, Grumbach MM. Ontogeny of gonadotropin secretion in congenital anorchism: sexual dimorphism versus syndrome of gonadal dysgenesis and diagnostic considerations. J Urol 1987;138:587-91.

5. Davenport M, Brain C, Vandenberg C, et al. The use of the hCG stimulation test in the endocrine evaluation of cryptorchidism. Br J Urol 1995; 76:790-4.

6. Forest MG. Pattern of the response of testosterone and its precursors to human chorionic gonadotropin stimulation in relation to age in infants and children. J Clin Endocrinol Metab 1979;49:132-7.

7. Forest MG, David M, Lecoq A, Jeune M, Bertrans J. Kinetics of the HCG-induced steroidogenic response of the human testis. III. Studies in children of the plasma levels of testosterone and HCG: rationale for testicular stimulation test. Pediatr Res 1980;14:819-24.

8. Scholler R, Roger M, Leymarie P, et al. Evaluation of Leydig-cell function in normal prepubertal and pubertal boys. J Steroid Biochem 1975;6: 95-9.

9. Urban MD, Lee PA, Lanes R, Migeon CJ. HCG stimulation in children with cryptorchidism. Clin Pediatr (Phila) 1987;26:512-4.

10. Winter JSD, Taraska S, Faiman C. The hormonal response to HCG stimulation in male children and adolescents. J Clin Endocrinol Metab 1972;34:348-53

11. Lee MM, Donahoe PK. Mullerian inhibiting substance: a gonadal hormone with multiple functions. Endocr Rev 1993;14:152-64.

12. Josso N, Cate RL, Picard JY, et al. Anti-mullerian hormone: the Jost factor. Recent Prog Horm Res 1993;48:1-59.

13. Lee MM, Donahoe PK, Hasegawa $T$, et al. Mullerian inhibiting substance in humans: normal levels from infancy to adulthood. J Clin Endo crinol Metab 1996;81:571-6.

14. Jost A. Recherches sur la différenciation sexuelle de l'embryon de lapin. Arch Anat Microsc Morphol Exp 1946-1947;36:271-315.

15. Josso N, Lamarre I, Picard JY, et al. Anti-mullerian hormone in early human development. Early Hum Dev 1993;33:91-9.
16. Baker ML, Metcalfe SA, Hutson JM. Serum levels of mullerian inhib iting substance in boys from birth to 18 years, as determined by enzyme immunoassay. J Clin Endocrinol Metab 1990;70:11-5.

17. Hudson PL, Dougas I, Donahoe PK, et al. An immunoassay to detect human mullerian inhibiting substance in males and females during normal development. J Clin Endocrinol Metab 1990;70:16-22.

18. Josso N, Legeai L, Forest MG, Chaussain JL, Brauner R. An enzyme linked immunoassay for anti-mullerian hormone: a new tool for the evaluation of testicular function in infants and children. J Clin Endocrinol Metab 1990;70:23-7.

19. Gustafson ML, Lee MM, Asmundson L, MacLaughlin DT, Donahoe PK. Mullerian inhibiting substance in the diagnosis and management of intersex and gonadal abnormalities. J Pediatr Surg 1993;28:439-44.

20. Winter JSD, Hughes IA, Reyes FI, Faiman C. Pituitary-gonadal relations in infancy. 2. Patterns of serum gonadal steroid concentrations in man from birth to two years of age. J Clin Endocrinol Metab 1976;42: 679-86.

21. Forest MG, Sizonenko PC, Cathiard AM, Bertrand J. Hypophysogonadal function in humans during the first year of life. 1. Evidence for testicular activity in early infancy. J Clin Invest 1974;53:819-28.

22. Miettinen OS. Estimation of relative risk from individually matched series. Biometrics 1970;26:75-86.

23. Vollset SE. Confidence intervals for a binomial proportion. Stat Med 1993;12:809-24. [Erratum, Stat Med 1995;14:875.]

24. Josso N, Boussin L, Knebelmann B, Nihoul-Fékété C, Picard JY. Antimullerian hormone and intersex states. Trends Endocrinol Metab 1991;2: 227-33

25. Josso N. Paediatric applications of anti-mullerian hormone research: 1992 Andrea Prader Lecture. Horm Res 1995;43:243-8.

26. Rey R, Lordereau-Richard I, Carel J-C, et al. Anti-mullerian hormone and testosterone serum levels are inversely related during normal and pre cocious pubertal development. J Clin Endocrinol Metab 1993;77:1220-

27. Baker ML, Hutson JM. Serum levels of mullerian inhibiting substance in boys throughout puberty and in the first two years of life. J Clin Endocrinol Metab 1993;76:245-7.

28. Gustafson ML, Lee MM, Scully RE, et al. Müllerian inhibiting substance as a marker for ovarian sex-cord tumor. N Engl J Med 1992;326: 466-71.

29. Rey RA, Lhomme C, Marcillac I, et al. Antimullerian hormone as serum marker of granulosa cell tumors of the ovary: comparative study with serum alpha-inhibin and estradiol. Am J Obstet Gynecol 1996;174: 958-65.

30. Imbeaud S, Carre-Eusebe D, Rey R, Belville C, Josso N, Picard JY. Molecular genetics of the persistent mullerian duct syndrome: a study of 19 families. Hum Mol Genet 1994;3:125-31.

31. Orth JM, Gunsalus GL, Lamperti AA. Evidence from Sertoli celldepleted rats indicates that spermatid number in adults depends on numbers of Sertoli cells produced during perinatal development. Endocrinology 1988;122:787-94.

32. Rey R, Mebarki F, Forest MG, et al. Anti-mullerian hormone in children with androgen insensitivity. J Clin Endocrinol Metab 1994;79:960- 